\title{
TOWARDS CURBING GLOBAL VILLAGE WARMING: NEPAL'S CONTRIBUTION TO MAKE A DIFFERENCE
}

\author{
Diwakar Poudyal, MSc.Ag. Econ. ${ }^{22}$
}

\begin{abstract}
The global warming has substantial direct and indirect impact on us, on the health of ecosystems and food and water sources. Warming has been rapid due to economic development with little care on the consequences toward mother earth's atmosphere, land and water systems. Lessons to Nepal include warming of snowy peaks, their quick melting and sooner depletion of snow stocks; increased probability of sudden floods and desertification, changing crop zones; productivity regimes, patterns, maturity days, ecology; insects, predators, diseases their degree of occurrence, types or characteristics etc., so that concerns and priorities to research would be changed. Planting a tree in the backyard, practicing better urban disposals systems, encouraging individual choices such as un plugging a freezer, replacing incandescent bulbs with more efficient ones, sealing and insulating heating and cooling devices and food boxes, using solar, wind or geo-thermal resources whenever possible, joining a group of bicyclists, or mass transit; or resistance to an extreme weather, fuel use for cooking or warming food all can make a difference. It was felt that a single country can do little, but even the little would be of great value. Nepal can help reduce global warming by taking steps such as harnessing river systems soon for clean energy and offer benefits to the global community through safeguarded bio-diversity to maintain genetic system. Nepal should adapt to the bio-secure initiatives for meeting food needs locally and needs to let policymakers and leaders know and win confidence to this concern with support on study on Glaciers in Nepal and monitor the global warming situation and contribute by further seeking realistic small ways to reduce global warming. We can control hazards by raising awareness and exploring smaller and practical approaches at grass root level.
\end{abstract}

\section{Introduction}

Why the ice is melting? The primary answer is factors that increase earth's warmth are in more active mode and the factors responsible to bring down temperature are lesser than desired at work. The economic development, modernization or industrialization with little care on the consequences toward mother earth's atmosphere, land, water, bio-diversity and production and consumption pattern that has been resulting to emission of greenhouse creating and ozone depleting type of gases and is the cause of climate change and increased warmth and hence melting ice. Excessive damage of forests, unplanned development of cities, towns and rural areas with more of congestion, over use of resources than is required pose issues as all these cause warming. Below is a summary of what has been reported on such factors in more recent decades.

Taking Nepal as a case, in the last three decades the average air temperature measured at 49 stations rose by 1 oC, with high elevation sites warming the most (Shrestha et al., 1999). This was twice as fast as the $0.6 \mathrm{oC}$ average warming for the mid-latitudinal Northern Hemisphere 24 to 40 o.N over the same time period indicating that there is high sensitivity of mountain regions to climate change.

\footnotetext{
22 Joint Secretary, Monitoring and Evaluation Division, Ministry of Agriculture and Cooperatives, Singhdurbar.

Email: dibakarpaudyal@hotmail.com
} 
In the Asian region, India, including southern India, did experience a warming trend at a rate of 0.6 oC per century (IPCC, 2001b; NCDC, 1999). The average temperature for Taiwan rose by 1 to $1.4 \mathrm{oC}$ in the last 100 years. For Afghanistan the average temperature for 2000 was the warmest on record (Hsu and Chen, 2002). Arid Central Asia, which includes Afghanistan, had warmest winter on record in the year 2001, and experienced a warming of 1-2 oC during the 20th century (IPCC, 1998; WMO, 2002b). Ice core records from the Dasuopu Glacier in Tibet indicated that the last decade and last 50 years were the warmest in 1,000 years (Thompson et al., 2000). As per the meteorological records for the Tibetan Plateau the annual temperatures increased 0.16 oC per decade and winter temperatures by 0.32 oC per decade from 1955 to 1996 (Liu and Chen, 2000). In Mongolia a 1,738-year tree-ring record from remote alpine forests in the Tarvagatay Mountains indicated that 20th century temperatures in this region were the warmest of the last millennium. Tree growth during 1980-1999 was the highest of any 20-year period on record, and 8 of the 10 highest growth years occurred since 1950. The 20th century warming was observed in tree-ring reconstructions of temperature from widespread regions of Eurasia, including sites in the Polar Urals, Yakutia, and the Taymir Peninsula, Russia (D.Arrigo, 2001). The average annual temperature in Mongolia increased by about 0.7 oC over the past 50 years.

In Europe, South America, Australia or else where the following kind of evidence is drawn. In Southeast Europe and Middle East the temperatures reached as high as $43.8 \mathrm{oC}$ in locations across Turkey, Greece, Romania, Italy, and Bulgaria. In Bulgaria, 100-year records for daily maximum temperature were broken at more than $75 \%$ of the observing stations on July. For Armenia, 2000 was the hottest summer of the century with widespread heat wave in JulyAugust 2000.. Jordan reported the longest stretch of summer heat in its 77-year record (NCDC, 2000; WMO, 2000/, 2001). Continental Europe warmed 0.8 oC during the past century, with the last decade being the warmest on record (IPCC, 2001b). In Germany temperatures were as much as 4 oC above average (WMO, 2002a) with warmest October on record, 2001. The record-breaking temperatures occurred in the context of a warming trend of $0.8 \mathrm{oC}$ over continental Europe during the past century. Over the 20th century Central England temperature warmed by about $0.5 \mathrm{oC}$ with warmest October on record, 2001. Four of the five warmest years in the 343-year record occurred in the last decade (Hulme, 1999). In Australia, an average annual temperature increase of $0.5-1.0$ oC per decade over the past century (Collins, 2002; Reuters 2002) with warmest April on record, 2002 was noted. There has also been an increase in warm days and a decrease in cold winter days. The temperature in the high plateau region in extreme southeastern Peru also raised $2 \mathrm{oC}$, from an average of $9 \mathrm{oC}$ in the 1960s to 11 oC in 2001 (Inter-Press Service, 2001). In Tropical Andes (Ecuador, Peru, Bolivia, and northernmost Chile) the average annual temperature increased by about 0.1 oC per decade since 1939. The rate of warming doubled in the last 40 years, and more than tripled in the last 25 years, to about 0.33 oC per decade (Vuille and Bradley, 2000).

\section{What is happening due to global warming?}

The above information clearly indicate what the consequences would be on various aspects such as patterns of seasons and their effect on production, growth and migration cycles and other biological behaviors and on human health and diseases. The huge damage is in the form of reduced biodiversity due to extinction of plant and animal life species in the oceans and lands. The melting of ice alone creating extinction of natural storage systems of ice means something the mother earth is shaken to adjust such volume to the oceans, meaning rise in sea levels. The consequences to rise in sea level would mean many things. The penetration or flow alone of these might be having consequences of unthinkable dimensions. Following is a brief note on such issues. 


\section{Glaciers melting}

Glaciers melting can be taken as one of the most serious consequence of global warming in so far Nepal is concerned. The upward shift in snow line and melting aspect of glaciers makes Nepal a directly highly vulnerable country to suffer from the climate change due to actions exercised else where. Globally, over the past 150 years, the majority of mountain glaciers monitored have been shrinking. Many glaciers at lower latitudes are now disappearing, and scientists predict that, under some plausible warming scenarios, the majority of glaciers will be gone by the year 2100 . As glaciers continue to shrink, summer water flows will drop sharply, disrupting an important source of water for irrigation and power in many areas that rely on mountain watersheds.

\section{Himalayan and other glaciers retreating, thinning, receding and disappearing}

The Khumbu Glacier, popular climbing route to the summit of Mt. Everest, has retreated over 5 $\mathrm{km}$ since 1953 (UNEP, 2002). Since the Himalayan region overall has warmed by about $1{ }^{\circ} \mathrm{C}$ since the 1970s, glaciers in the Himalayas like else where are retreating. The average rate is $15 \mathrm{~m}$ per year (Geological Survey of India, 1999). It is consistent with the rapid warming recorded at Himalayan climate stations since the 1970s. Winter stream flow for the Baspa glacier basin has increased 75\% since 1966 and local winter temperatures have warmed, suggesting increased glacier melting in winter (Kulkarini et al., 2002). As Himalayan glaciers melt glacial lakes are swelling and in danger of catastrophic flooding eminent. The average glacial retreat for Bhutan was 30-40 m per year (ICIMOD, 2002). Glaciers in Patagonia in Argentina have receded by an average of almost $1.5 \mathrm{~km}$ over the last 13 years (Wessels et al., 2001; Painter, 2001). There has been an increase in maximum, minimum, and average daily temperatures of more than $1{ }^{\circ} \mathrm{C}$ over the past century in southern Patagonia, east of the Andes. Since 1947 Australia's 34 glaciers (Heard Island) have decreased by $11 \%$ in area and $12 \%$ in volume, with half the loss occurring in the 1980s. Air temperature has risen $0.7^{\circ} \mathrm{C}$ between 1947 and 2001 (Pockely, 2001; Reuters, 2001a). During 1959-1988, 1,081 glaciers in the Pamir-Altai disappeared with increased temperatures in the mountains of Kyrgyztan by $0.5-1.5{ }^{\circ} \mathrm{C}$ since the 1950 s (UNEP, 2000). Similarly of the six glaciers in the Venezuelan Andes in 1972, only 2 remain, and scientists predict that these will be gone within the next 10 years (OSU, 2001). Glaciers in the mountains of Colombia, Ecuador, and Peru show similar rapid rates of retreat (Schubert, 1999). Temperature records in other regions of the Andes show a significant warming of about $0.33^{\circ} \mathrm{C}$ per decade since the mid-1970s (Vuille and Bradley, 2000). Pity enough, the ice of the Mount Kilmanjaro of Tanzania is projected to disappear by 2020 . $82 \%$ of its ice has already disappeared since 1912, with about one-third melting in just the last dozen years. At this rate, all of the ice will be gone in about 15 years (OSU, 2001). Scientists hypothesize that less snow on the mountain during the rainy season decreases the surface reflective ness, leading to higher rates of absorption of heat and increased ice melt (Hardy, 2002). Similarly, since the 1990s, glacier area of Rwenzori Mountains, Uganda has decreased by about 75\% (Kaser, 1999).

The continent of Africa warmed by $0.5^{\circ} \mathrm{C}$ during the past century, and the five warmest years in Africa have all occurred since 1988. Similarly in the north Americas, the Athabasca Glacier in the Canadian Rockies has retreated $0.5 \mathrm{~km}$ in the last 60 years and has thinned dramatically since the 1950s-60s (State of the Canadian Cryosphere, 2002). In British Columbia the Wedgemont Glacier retreated hundreds of meters since 1979, as the climate warmed at a rate of $1.1^{\circ} \mathrm{C}$ per century, twice the global average (BC Ministry of Water, Land, and Air Protection, 2002). In Alaska a study of 67 glaciers showed that between the mid-1950s and mid-1990s the glaciers thinned by an average of about $0.5 \mathrm{~m}$ per year. Repeat measurements on 28 of those glaciers show that from the mid-1990s to 2000-2001 the rate of thinning had increased to nearly $1.8 \mathrm{~m}$ per year (Arendt et al., 2002). Alaska has experienced a rapid warming since the 
1960s. Annual average temperatures have warmed up to $1{ }^{\circ} \mathrm{C}$ per decade over the last three decades, and winter warming has been as high as $2{ }^{\circ} \mathrm{C}$ per decade (Alaska Regional Assessment Group, 1999). Similarly there has been a Rapid thinning of the Greenland ice sheet in coastal areas, especially of outlet glaciers, as was measured in two studies during the 1990s (Krabill et al., 2000). The coastal land ice loss is attributed to a combination of warming-driven factors, including increased melting during warmer summers, high snow accumulation rates feeding the outlet glaciers, and increased rates of melting at the bottom of glaciers due to ocean warming (Rignot and Thomas, 2002).

\section{Warming ocean, rising sea-level and flooding coastal areas}

Warmer temperatures increase melting of mountain glaciers, increase ocean heat content, and cause ocean water to expand. Largely as a result of these effects, global sea level has risen 10$25 \mathrm{~cm}$ over the past 100 years. With additional warming, sea level is projected to rise from 15$92 \mathrm{~cm}$ more during the next 100 years. On average, 15-30 meters of beach are lost for every foot ( 0.3 meters) of sea-level rise. Local land subsidence (sinking) and/or uplift due to geologic forces and coastal development affect the rate of coastal land loss.

\begin{tabular}{|l|l|}
\hline $\begin{array}{l}\text { Chokoria Sundarbans, Bangladesh (Flooded } \\
\text { mangroves) }\end{array}$ & $\begin{array}{l}\text { With rising ocean levels flooding in about 7,500 hectares } \\
\text { of mangrove forest during the past three decades }\end{array}$ \\
\hline China - Rising waters and temperature & $\begin{array}{l}\text { With average rate of sea-level rise } 0.09+/-0.04 \\
\text { inches/yr over the last 30 years }\end{array}$ \\
\hline $\begin{array}{l}\text { Worldwide ocean warming with a net warming } \\
\text { of } 0.06^{\circ} \mathrm{C} \text { from the sea surface to a depth of } \\
3000 \mathrm{~m}\end{array}$ & $\begin{array}{l}\text { Over the past } 35-45 \text { years with more than half of the } \\
\text { increase in heat content that occurred in the upper } 300 \\
\mathrm{~m} \text { and was warmed by } 0.31^{\circ} \mathrm{C} \text { suggesting that the oceans } \\
\text { are taking up excess heat as the atmosphere warms }\end{array}$ \\
\hline $\begin{array}{l}\text { World Ocean - Southern Ocean - Strong warming } \\
\text { trend with a 0.17 oC rise in ocean temperatures } \\
\text { between the } 1950 \text { s and the 1980s }\end{array}$ & $\begin{array}{l}\text { New Zealand - Ocean warming with consistent global } \\
\text { average upward trend }(1-2 \mathrm{~mm}) \text { per year }\end{array}$ \\
\hline
\end{tabular}

\section{Warmer Arctic and Antarctic regions}

Parts of Canada, Alaska, Siberia, and the Antarctic have been experiencing warming well above the global average for the past few decades. This trend fits climate model predictions for a world with increasing levels of greenhouse gases. Melting permafrost is forcing the reconstruction of roads, airports, and buildings and is increasing erosion and the frequency of landslides. Reduced sea ice and ice shelves, changes in snowfall, and pest infestations have affected native plants and animals that provide food and resources to many people.

\begin{tabular}{|l|l|}
\hline $\begin{array}{l}\text { Arctic Ocean and Antarctica. Ice thickness at } \\
29 \text { stations, as measured by submarine sonar, } \\
\text { decreased by an average of more than } 1.2 \mathrm{~m} \\
\text { compared to } 20 \text { to } 40 \text { years ago }\end{array}$ & $\begin{array}{l}\text { From } 1966 \text { to } 1995 \text {, annual temperatures in the Arctic } \\
\text { increased by as much as } 1{ }^{\circ} \mathrm{C} \text { per decade, and spring } \\
\text { temperatures increased by as much as } 2{ }^{\circ} \mathrm{C} \text { per } \\
\text { decade }\end{array}$ \\
\hline $\begin{array}{l}\text { The permanent ice cover of nine lakes on } \\
\text { Signey Island has decreased by about 45\% } \\
\text { since the } 1950 \text { s. }\end{array}$ & Average summer air temperature has warmed by $1{ }^{\circ} \mathrm{C}$ \\
\hline $\begin{array}{l}\text { Antarctic Peninsula and Siberia - Collapsing } \\
\text { ice shelf and melting permafrost }\end{array}$ & $\begin{array}{l}\text { The ice retreat is attributed to the region's strong } \\
\text { warming trend } 2.5^{\circ} \mathrm{C} \text { in the last } 50 \text { years }\end{array}$ \\
\hline
\end{tabular}




\section{Heavy rains, snowfalls, and flooding}

A warmer climate will bring an increase in precipitation worldwide, especially during winter and in mid- to high latitudes, according to climate model projections. In addition, more precipitation is expected to fall in downpours and heavy snowstorms leading to increased flooding and damages. The area of the U.S. affected by extreme rainfall has increased significantly since 1910. Heavy rainfalls have also increased in Japan, the former Soviet Union, China, and Australia. As climate change increases the risk of flooding, human changes in land use and land cover can also contribute to the growing risk of flooding. Thus on the whole, heavier rains, worst flooding, wettest years such are the characteristics of global warming.

\begin{tabular}{|l|l|}
\hline In Buenos Aires, Argentina $34.2 \mathrm{~cm}$ of rain & $\begin{array}{l}\text { More than } 4 \text { times the average monthly rainfall, just in } 5 \\
\text { days }\end{array}$ \\
\hline $\begin{array}{l}\text { The Pampas region of Uruguay were } \\
\text { flooded after } 3 \text { months of high rainfall } \\
\text { August to October } 2001\end{array}$ & $\begin{array}{l}\text { Mean annual precipitation in the humid Pampa increased } \\
\text { by 35\% in the last half of the 20th century }\end{array}$ \\
\hline $\begin{array}{l}\text { In Venezuela heaviest rainfall in } 100 \text { years } \\
\text { Caused massive landslides and flooding that killed } \\
\text { approximately 30,000 people in December 1999 }\end{array}$ \\
\hline $\begin{array}{l}\text { In the Southeastern Norway the year 2000 } \\
\text { was the wettest year since records began in } \\
1895\end{array}$ & $\begin{array}{l}\text { Precipitation in northern Europe has increased 10-40\% in } \\
\text { the last century (IPCC, 2001b). }\end{array}$ \\
\hline
\end{tabular}

Droughts, fires and disappearing lakes

Not only heavy rains but just opposite is also the evidence due to global warming. As the climate heats up, droughts are expected to become more frequent and severe in some locations. Sustained drought makes wildfires more likely, and crops and trees more vulnerable to pest infestations and disease. Generally, local land use and land cover changes can exacerbate the climate change-driven increase in drought risk. For example, in the tropics, "slash-and-burn" land clearing practices can trigger large fires during extended droughts.

In Asia Pakistan, Tajikistan, Korea have experience of draught. Pakistan was recorded having the longest drought on record, 1999-2001. The prolonged three-year drought, which covers much of South West Asia, has affected 2.2 million people and 16 million livestock in Pakistan (WMO, 2002b). Similarly, In Iran, ninety percent of wetlands dried up after 2 years of extreme drought. Much of South West Asia experienced a prolonged three-year drought that is unusual in its magnitude. Out of 102 years of record, 1999, 2000, and 2001 rank as the fifth, third, and seventh driest on record. 1999-2000 was the driest winter on record (NCDC, 2002b). Similarly, Tajikistan rocorded Lowest rainfall in 75 years. 2001 marked the third consecutive year of drought, which destroyed half the wheat crop (UN, 2001). In the Far east Korea was worst drought in 100 years of record. It coincided with an average annual temperature increase in Asia's temperate region, which includes Korea, by more than $1{ }^{\circ} \mathrm{C}$ over the past century. The warming has been most pronounced since 1970(AFP, 2001; NCDC, 2001; CNN, 2001). Experience with Kenya is of worst drought in 60 years in 2001. Over four million people were affected by a severely reduced harvest, weakened livestock, and poor sanitary conditions (USAID, 2001).

The examples of fire outbreak are recorded for Samos Island, Greece, Argentina and South Africa. Fires due to dry conditions and record-breaking heat in July 2000 consumed one-fifth of the island. Temperatures reached up to $40{ }^{\circ} \mathrm{C}$ in some areas. Averaged over the continent, Europe has warmed $0.8^{\circ} \mathrm{C}$ during the past century. Similarly 1.5 million hectares burned in La Pampa province of Argentina, sustained by record temperatures and persistent drought (NOAA- 
Office of Global Programs, 2001). Annual average temperature in Argentina has increased by nearly $1{ }^{\circ} \mathrm{C}$ over the last century (Hulme and Sheard, 1999). Similarly Burning shores in South Africa in January 2000, as one of the driest Decembers on record and temperatures over $40^{\circ} \mathrm{C}$ recorded fueled extensive fires along the coast in the Western Cape Province. The fire intensity was exacerbated by the presence of invasive vegetation species, some of which give off $300 \%$ more heat when burned compared to natural vegetation (IFFN, 2000). The case of Disappearing lake is recorded recently for Lake Chad. The surface area of the lake has decreased from $25,000 \mathrm{~km}^{2}$ in 1963 to $1,350 \mathrm{~km}^{2}$ today. Modeling studies indicated that the severe reduction results from a combination of reduced rainfall and increased demand for water for agricultural irrigation and other human needs (Coe and Foley, 2001). Even quite large in dimension is the scene in China, where more than half of the 4,000 lakes in the Qinghai province are disappearing due to drought. The severity of the impact is exacerbated by over pumping of aquifers (Reuters, 2001b). Annual average temperature in China has increased during the past century, with pronounced warming since 1980 (NCDC, 1999). Most of the warming has been in northern areas, including Qinghai Province, and in the winter.

\section{Pre arrival of spring}

Spring now arrives earlier in many parts of the world. Evidence of this comes from earlier thaw dates for rivers and lakes; earlier dates for plant blooming and leafing; and earlier animal egglaying, spawning and migration. An earlier spring may disrupt animal migrations, alter competitive balances among species, and cause other unforeseen problems.

\begin{tabular}{|c|c|}
\hline $\begin{array}{l}\text { In Tornionjoki River, Finland Spring ice } \\
\text { breakup now comes about } 7 \text { days earlier } \\
\text { compared to a century ago }\end{array}$ & $\begin{array}{l}\text { Thirty-eight of } 39 \text { records of ice cover from throughout } \\
\text { the Northern Hemisphere show a trend toward earlier } \\
\text { spring ice breakup and later winter freezing between } \\
1846 \text { and } 1995\end{array}$ \\
\hline $\begin{array}{l}\text { In Lake Baikal, Russia winter freezing is } \\
\text { about } 11 \text { days later and spring ice breakup } \\
\text { is about } 5 \text { days earlier }\end{array}$ & $\begin{array}{l}\text { Largest rates of warming since } 1976 \text { over the mid-and } \\
\text { high latitude continental regions of the Northern } \\
\text { Hemisphere compared to a century ago }\end{array}$ \\
\hline Some regions of Siber & Warmed by as much as more than $1.4 \mathrm{oC}$ in just 25 years \\
\hline $\begin{array}{l}\text { In The } \\
\text { of motr }\end{array}$ & small moths \\
\hline In Hur & $\begin{array}{l}\text { For the locust tree } 3-8 \text { days. Period: } 1983-1994 \\
\text { compared to } 1851-1930 .\end{array}$ \\
\hline spring and & nat \\
\hline $\begin{array}{l}\text { Annual average temperature over } \\
\text { continental Europe has increased } 0.8^{\circ} \mathrm{C} \\
\text { over the past century }\end{array}$ & $\begin{array}{l}\text { A study of the timing of leaf unfolding for four tree } \\
\text { species shows that from } 1969 \text { to } 1998 \text { the beginning of } \\
\text { the growing season has advanced by } 8 \text { days. }\end{array}$ \\
\hline $\begin{array}{l}\text { Turku, Finland the start of the gron } \\
\text { season has progressively earlier }\end{array}$ & By betn \\
\hline $\begin{array}{l}\text { One of the most comprehensive studies of } \\
\text { plant species in Britain revealed that the } \\
\text { average first flowering date of } 385 \text { British } \\
\text { plant species has advanced }\end{array}$ & $\begin{array}{l}16 \% \text { of species flowered significantly earlier in the } 1990 \mathrm{~s} \\
\text { than previously, with an average advancement of } 15 \\
\text { days in a decade }\end{array}$ \\
\hline . & \\
\hline
\end{tabular}




\begin{tabular}{|l|l|}
\hline from hibernation noted. & 23 days earlier than 23 years ago. \\
\hline $\begin{array}{l}\text { Southeast Arizona, the Mexican jays laying } \\
\text { eggs } 10 \text { days earlier than in } 1971\end{array}$ & $\begin{array}{l}\text { Earlier breeding coincides with a nearly } 2.8^{\circ} \mathrm{C} \text { increase } \\
\text { in average night time temperatures from } 1971 \text { to } 1998\end{array}$ \\
\hline
\end{tabular}

\section{Shifts in the plant and animal range, squeeze in biodiversity and population}

Plants and animals generally react to consistently warmer temperatures by moving to higher latitudes and elevations. Recent studies reveal that some species have already started to shift their ranges, consistent with warming trends. Many populations and species have become more vulnerable to declining numbers or extinction occurred faster than they could respond. The following examples can be cited.

\begin{tabular}{|l|l|}
\hline $\begin{array}{l}\text { In Alaska - Changing vegetation patterns } \\
\text { are noted. }\end{array}$ & $\begin{array}{l}\text { Photographs taken in 1948-50 and in 1999-2000 of the } \\
\text { area between the Brooks Range and the Arctic coast } \\
\text { show an increase in shrub abundance in tundra areas, } \\
\text { and an increase in the extent and density of spruce } \\
\text { forest }\end{array}$ \\
\hline $\begin{array}{l}\text { Argentine Islands the populations of two } \\
\text { native Antarctic flowering plants increased } \\
\text { rapidly between } 1964 \text { and } 1990\end{array}$ & $\begin{array}{l}\text { Coincident with the strong regional warming over the } \\
\text { Antarctic Peninsula }\end{array}$ \\
\hline $\begin{array}{l}\text { In the UK the birds have extended to } \\
\text { northern ranges }\end{array}$ & $\begin{array}{l}\text { The northern margins for many species had moved } \\
\text { northwards by an average of about } 19 \text { km }\end{array}$ \\
\hline $\begin{array}{l}\text { In Western Hudson Bay, Canada decreased } \\
\text { weight in adult polar bears (stress } \\
\text { condition) }\end{array}$ & $\begin{array}{l}\text { Rising spring temperatures have shortened the spring } \\
\text { hunting season by two weeks over the last two decades }\end{array}$ \\
\hline $\begin{array}{l}\text { In Fiji, in the year } 2000 \text { repeated and } \\
\text { prolonged bleaching }\end{array}$ & $\begin{array}{l}\text { Tropical water temperatures warm with climate change } \\
\text { - eventually killed corals and caused a decline in } \\
\text { associated marine species }\end{array}$ \\
\hline
\end{tabular}

\section{Bleaching of coral reef}

Reefs in 32 countries experienced dramatic bleaching in 1997-98. Bleaching results from the loss of microscopic algae that both color and nourish living corals. Water that is warmer than normal by only $1.1-1.6^{\circ} \mathrm{C}$ has been linked to bleaching.

\begin{tabular}{l|l|}
\hline In Galapagos, Ecuador - Sea-surface & climate change - eventually kill corals and cause a \\
temperatures in March/April 2002. rose \\
above $27.5^{\circ} \mathrm{C}$ several times
\end{tabular}

\section{The incidence of diseases}

Warmer temperatures allow mosquitoes that transmit diseases such as malaria and dengue fever to extend their ranges and increase both their biting rate and their ability to infect humans. Ecologists have identified the first genetic adaptation to global warming in the North American mosquito Wyeomyia smithii. Modern mosquitoes wait nine days more than their ancestors did 30 years ago before they begin their winter dormancy, with warmer autumns being the most likely cause (Bradshaw and Holzapfel, 2001). Higher temperatures, enhancing mosquito survival rates, population growth and biting rates, can increase the risk of disease transmission (Gubler, et al., 2001). 
In the case of neighboring Bangladesh - Link between stronger El Nino events and cholera prevalence was shown; and a strong case for the climate-health link by providing evidence for biological sensitivity to climate, meteorological evidence of climate change, and evidence of epidemiological change with global warming is shown. The study likely represents the first piece of evidence that warming trends over the last century are affecting human disease (Patz, 2002).

\section{Lessons learnt}

- Nepal, as a developing country need to believe in the following, since, by and large, Nepal is not a rich knowledge based country. Nepal needs to be loud and clear in the following matters:

- As the global village is warming Nepal's snowy peaks are quickly melting.

- As glaciers, their move is accelerated, and as snows the stock with us is depleting soon.

- Because of such events due to rise in temperatures, in the long run, we might be faced with sudden floods and gradual desertification just below the snow line altitudes.

- Our crop choices would be changed and new crop zones may be formed due to shifts in temperature.

- The crop productivity and their rankings, cropping patterns and maturity days could be changed in the long run.

- The ecology and its pattern would have shifted

- The migratory birds, their seasons would change thus causing change in the tourist industry.

- The insects, predators, diseases their degree of occurrence, types or characteristics might change, thus causing concerns and confusions to changed research priorities.

- We must actively involve in reducing hazardous actions, support and enhance bio-secure and bio-diversity friendly initiatives; and use all sustainability principles in a dynamic mode.

- Use products, resources or services in such a way that we least affect mother earth through shielding of gases and rupture of ozone layer.

\section{What Nepal can do?}

It is of course a dilemma that a single country can really do little even if it were a prosperous and wealthy nation. But even the little would prove to be of great value to the humanity if some thing unique can be done, spared or shown as an example to the whole world. The developed world is advocating on something that is of only little relevance to us as a country. But as we have this little planet to share, the efforts of both developing and developed countries contribute highly significantly.

Planting a tree in the backyard and avoiding electric fan for an hour or so can make a difference. The plant residues like stubbles, banmara, or night soil and animal dung used to augment fuel for cooking and warming foods and water or devising power plants being operated through urban disposals like that that is planned by Beijing, China; all or any thing thought, advocated or done tend to contribute to stopping melting ice and reducing heated debates in a global scale.

Entire humanity now believes that even the individual choices can have an impact on global climate change. The feeling is that, in the western world, the car a person drives and the kind of fuel used in it influences the most important personal climate decision. Such affluence is not with us at the moment. However, even in our context, the electric power or the light some one chooses or saves has significant meaning. Unplugging a freezer, replacing 
incandescent bulbs with more efficient compact fluorescents is one quick way to reduce global warming applicable to us as well. Similarly, installing a programmable thermostat or sealing and insulating heating and cooling ducts can each reduce carbon dioxide emissions? Using solar, wind or geo-thermal resources whenever possible to heat or generate power, or joining a carpool or taking mass transit would mean a happier planet. The style of how we are prepared to resist to an extreme weather, indulge in using type of fuel to cook and how many time the same thing we warm as we have no insulated food boxes makes some difference on the degree of warming.

\section{Suggested area in reduction of global warming in Nepal}

- The perennial river systems potentially offer clean energy. We have so many rivers that are not yet tapped even around the National highways. We are not letting our people join hands for power generation in the name of holding license or keeping information secret but not doing the job. We should exploit this potential as soon as possible.

- Nepal has an unique position in terms of offering benefits to the global community through safeguarded bio-diversity in order to maintain or sustain the genetic system. Despite the smallness of geographic coverage, Nepal with her lowest $70 \mathrm{~m}$. to highest altitude range of $8848 \mathrm{~m}$. there is no plant or animal type on land that has no scope to thrive. The issues associated to temperature rise in terms of maintaining the varieties, in a global perspective, perhaps offers Nepal work as a most safe haven. In this sense, Nepal has very high potentials to offer to the whole world.

- The organically friendly or bio-secure initiatives -farming with an appropriate mix of fruit plantation, vegetable, cash crops and cereal-pulse mix and meeting food consumption needs at local level and thus minimizing transport also help offer significant ground to reduce the hot topic of melting ice. Since in all cases the end results would be reducing shielding agents like carbon dioxide and other gases and minimizing ozone rupture.

- Nepal can serve as a venue for study and understanding global warming due to her uniqueness of altitudinal diversity. We should like to let policymakers and leaders know and win confidence that we are concerned about warming.

- Accesses and study on Glaciers in Nepal should be encouraged to monitor the global warming situation. We can contribute the global community in this frontier.

- Control of forest fire is yet another area which will help reduce global warming as each year thousands of hectares of forest lands is destroyed this way.

- Raising awareness and exploring smaller and practical ways and approaches to reducing global warming at grass roots levels such as village schools, rural communities will have to be encouraged with "small is beautiful" in mind.

- Global community and prosperous countries need to listen to and realize that the poor and rural poor are also concerned and can contribute to reduce global warming. These most valuable citizens of this critical century should be offered with opportunities of education, awareness and access to resources so that they stop burning animal dung and forest woods to lessen global warming. For sure forest woods and animal dung are not a luxury but a compulsion that add up to undesirable addition on global warming.

- Planning development of cities, towns and rural areas with a view to offer roads with no congestion or easy access must be thought right from now. Looking at Kathmandu 
as an example, we need to plan present bridges to work as over pass and construct straight short routes via underneath of bridges along river systems. Many of us now feel that we spend two liters of fuel for congested road and perhaps only half a liter for the distance we cover. Clearly, there is scope for reducing warming, and we can contribute via this strategy if we act promptly.

\section{Conclusion}

The global village warming has been rapid because each village in this globe has some warmth added each day. We must simply trust that if each village and households within it get worried and thereafter reduce some warmth each day, a day would come that the melting ice would decelerate doing so. Debates will have to, of course, continue even to happen this successfully due to continuity of awareness about our role and our actual act to this effect.

\section{REFERENCES}

1. AFP, 2001. Worst drought in a century hits Korean Peninsula. Agence France-Presse (AFP), June 10, 2001.

2. Alaska Regional Assessment Group, 1999. Preparing for a changing climate; The potential consequences of climate variability and change: Alaska. Center for Global Change and Arctic System Research, University of Alaska, Fairbanks, AK.

3. Bradshaw, W.E. and C.M. Holzapfel, 2001. Genetic shift in photoperiodic response correlated to global warming. Proceedings of the National Academies of Science http://www.pnas.org/, DOI: 10.1073/pnas.241391498 (see also: http://www.nature.com/nsu/nsu_pf/011108/011108-6.html).

4. Brown, J.L., S. Li, and N. Bhagabati, 1999. Long-term trend toward earlier breeding in an American bird: a response to global warming? Proceedings of the National Academy of Sciences, 96: 5565-5569.

5. Carter, T., 1998: Changes in the thermal growing season in Nordic countries during the past century and prospects for the future. Agricultural and Food Science in Finland, 7: 161-179.

6. CNN, 2001. South Korea drafts troops to fight 100-year drought . June 12, 2001. http://asia.cnn.com/2001/WORLD/asiapcf/east/06/12/skorea.drought.01/

7. Coe, M.T. and J.A. Foley, 2001. Human and natural impacts on the water resources of the Lake Chad basin, Journal of Geophysical Research (Atmospheres),106, D4: 3349-3356.

8. Collins, Dean, 2002. Personal communication confirming information in Reuters, 2002. Australian Bureau of Meteorology.

9. D'Arrigo, R. et al., 2001. 1,738 years of Mongolian temperature variability inferred from a tree-ring width chronology of Siberian Pine. Geophysical Research Letters, 28, 3: 543.

10. Ellis W.N., J.H. Donner and J.H, Kuchlein, 1997. Recent shifts in phenology of Microlepidoprera, related to climatic change (Lepidoptera). Entomologische Berricten (Amsterdam) 57: 66-72.

11. Fitter, A.H. and R.S.R. Fitter, 2002. Rapid Changes in Flowering Time in British Plants. Science, 296: 16891691.

12. Fowbert, J.A. and R.I.L. Smith, 1994. Rapid population increases in native vascular plants in the Argentine Islands, Antarctic Peninsula. Arctic and Alpine Research, 26, 3: 290-296.

13. Geological Survey of India, 1999. Inventory of the Himalayan Glaciers: A Contribution to the International Hydrological Programme, Special Publication No. 34, edited by M.K. Kaul.

14. Gille, S.T., 2002. Warming of the Southern Ocean since the 1950s. Science, 295: 1275-1277.

15. Goldman, E., 2002. Even in the High Arctic, nothing is permanent. Science, 297: 1493-1494.

16. Gubler, D.J., P. Reiter, K.L. Ebi, W. Yap, R. Nasci and J.A. Patz, 2001. Climate variability and change in the United States: Potential impacts on vector- and rodent-borne disease. Environmental Health Perspectives, 109, Supplement 2: 223-233.

17. Hardy, D., 2002. Kilimanjaro Climate \& Glaciers. http://www.geo.umass.edu/climate/kibo.html

18. Hsu, H.-H. and C.-T. Chen, 2002. Observed and projected climate change in Taiwan, Meteorology and Atmospheric Physics, 79, 1-2: 87-104.

19. Hulme, M. 1999. Air Temperature in Central England. Indicators of Climate Change in the UK, Department of the Environment, Transport, and the Regions.http://www.nbu.ac.uk/iccuk/

20. Hulme, M. and N Sheard, 1999. Climate Change Scenarios for Argentina. Climatic Research Unit, Norwich, UK. http://www.cru.uea.ac.uk/ mikeh/research/wwf.argent.pdf 
21. Huq, Z., et al. (eds.), 1999. Vulnerability and Adaptation to Climate Change for Bangladesh. Kluwer Academic Publisher, The Netherlands.

22. Ashford, G. and J. Castleden, 2001. Inuit Observations on Climate Change - Final Report. International Institute for Sustainable Development, Winnipeg, Manitoba, Canada. http://www.iisd.org/publications/publication.asp?pno=410

23. ICIMOD, 2002. Inventory of Glaciers, Glacial Lakes, and Glacial Lake Outburst Floods, Monitoring and Early Warning Systems in the Hindu Kush-Himalayan Region - Bhutan, International Centre for Integrated Mountain Development (ICIMOD) and United Nations Environment Programme. http://www.rrcap.unep.org/issues/glof/.

24. IFFN, 2000. Fires in the Southern Cape Peninsula, Western Cape Province, South Africa January 2000. IFFN, 22, April: 69-75.

25. Inouye, D.W. et al., 2000. Climate change is affecting altitudinal migrants and hibernating species. Proceedings of the National Academy of Sciences, 97, 4: 1630-1633.

26. IPCC, 1998. The Regional Impacts of Climate Change: An Assessment of Vulnerability. Special Report of the IPCC Working Group II, R.T. Watson, M.C. Zinyowera, R.H. Moss and D.J. Dokken, eds. Cambridge University Press, Cambridge, UK.

27. IPCC, 2001a. Climate Change 2001: The Scientific Basis. Intergovernmental Panel on Climate Change (IPCC) Working Group I, J.T. Houghton et al., eds. Cambridge University Press, Cambridge, UK.

28. IPCC, 2001b. Climate Change 2001: Impacts, Adaptation, and Vulnerability. Intergovernmental Panel on Climate Change (IPCC) Working Group II, MacCarthy, J.J. et al., eds. Cambridge University Press, Cambridge, UK.

29. Johannessen, O.M., E.V. Shalina, and M.W. Miles, 1999. Satellite evidence for an Arctic sea ice cover in transformation. Science, 286: 1937-1939.

30. Kaser, G., 1999. A review of modern fluctuations of tropical glaciers. Global and Planetary Change, 22: 93103.

31. Kulkarini, A.V., P. Mathur, B.P. Rathore, S. Alex, N. Thakur, M. Kumar, 2002. Effect of global warming on snow ablation pattern in the Himalaya. Current Science, 83, 2: 120-123.

32. Krabill, W., W. Abdalati, E. Frederick, S. Manizade, C. Martin, J. Sonntag, R. Swift, R. Thomas, W. Wright, and J. Yungel, 2000. Greenland Ice Sheet: High-Elevation Balance and Peripheral Thinning. Science, 289: 428-430.

33. Levitus, J., I. Antonov, T.P. Boyer, and C. Stephens, 2000. Warming of the World Ocean. Science, 287: 2225-2229.

34. Liu, X. and B. Chen, 2000. Climatic warming in the Tibetan Plateau during recent decades. International Journal of Climatology, 20: 1729-1742.

35. Magnuson, J. et al., 2000. Historical trends in lake and river ice cover in the Northern Hemisphere. Science, 289: 1743-1746.

36. Menzel, A. and P. Fabian, 1999. Growing season extended in Europe, Nature, 397: 659.

37. NCDC, 2001. Climate of 2001 - June Global Regional Analysis, July 13, 2001. National Climatic Data Center, Asheville,NC.http://lwf.ncdc.noaa.gov/oa/climate/research/2001/jun/global_regional.html\#Asia

38. NCDC, 2002a. Climate-Watch, May 2002. National Climatic Data Center, Asheville, NC. http://lwf.ncdc.noaa.gov/oa/climate/extremes/2002/may/extremes0502.html

39. NCDC, 2002b. Southwest Asia Eastern Mountains Drought - December 2001. National Climatic Data Center, Asheville,NC.http://lwf.ncdc.noaa.gov/oa/climate/research/2001/dec/swaem-drought-dec01.html

40. NIWA, 2002. New Zealand?s oceans are hotting up. Media Release, 18 April, 2002. National Institute of Water \& Atmospheric Research. Auckland, New Zealand.

41. NOAA-Office of Global Programs, 2001. Climate Information Project, NOAA Office of Global Programs. http://www.cip.ogp.noaa.gov/

42. NOAA-ORA/OSDPD Coral Reef Team, 2000. Experimental Coral Bleaching HotSpots for the year 2000. http://www.osdpd.noaa.gov/PSB/EPS/SST/climohot_2000.html.

43. NOAA-NESDIS, 2002. Sea surface temperature (SST) time series. National Environmental Satellite, Data, andinformation http://orbit-net.nesdis.noaa.gov/orad/sub/sst_series_24reefs.html

44. NSIDC (National Snow and Ice Data Center), 2002. Antarctic Ice Shelf Collapses. March 18, 2002. http://www.nsidc.org/iceshelves/larsenb2002/index.html

45. OSU, 2001. Ice caps in Africa, tropical South America likely to disappear within 15 years. Ohio State University press release.

46. http://www.acs.ohio-state.edu/units/research/archive/glacgone.htm 
47. Overpeck, J., K. Hughen, D. Hardy, R. Bradley, R. Case, M. Douglas, B. Finney, K. Gajewski, G. Jacoby, A. Jennings, S. Lamoureux, A. Lasca, G. MacDonald, J. Moore, M. Retelle, S. Smith, A.Wolfe and G. Zielinski, 1997. Arctic environmental change of the last four centuries. Science, 278: 1251-1256.

48. Painter, D., 2001. Melting glaciers signal global warming. Arizona State University News Release, May 29, 2001. http://clasdean.la.asu.edu/news/glacier.htm

49. Patz, J.A., 2002. A human disease indicator for the effects of recent global climate change. Proceedings of the National Academy of Sciences, 99, 20: 12506-12508.

50. Pockely, P., 2001. Climate change transforms island ecosystem. Nature, 410: 616.

51. W.C. Quayle, L.S. Peck, H. Peat, J.C. Ellis-Evans, P.R. Harrigan, 2002. Extreme responses to climate change in Antarctic lakes. Science, 295: 645.

52. Reuters, 2002. Australia has hottest April on record, article on May 6, 2002. Sydney, Australia.

53. Reuters, 2001a. Global warming melts Australia's glaciers. Article by Michael Perry, May 31, 2001, Sydney, Australia.

54. http://www.planetark.org/dailynewsstory.cfm/newsid/12711/story.htm

55. Rignot, Eric and Robert H. Thomas, 2002. Mass balance of polar ice sheets. Science, 297: 1502-1506.

56. Rodo, X., M. Pascual, G. Fuchs, and A.S.G. Faruque, 2002. ENSO and cholera: A non stationary link related to climate change? Proceedings of the National Academy of Sciences, 99, 20: 12901-12906.

57. Romanovsky, V.E., T.E. Osterkamp, T.S. Sazonova, N.I. Shender, V.T. Balobaev, 2000. Past and future changes in permafrost temperatures along the East Siberian Transect and an Alaskan Transect, Eos Trans. AGU, 81, 48, Fall Meet. Suppl., Abstract B71F-09.

58. Rothrock, D.A., Y. Yu, and G.A. Mayhut, 1999. Thinning of the Arctic sea-ice cover. Geophysical Research Letters 26, 23: 3469-3472.

59. Rozell, N., 2001. Alaska and Siberia Permafrost Thawing Together. Alaska Science Forum, Article \#1523, January 3, 2001.

60. http://www.gi.alaska.edu/ScienceForum/ASF15/1523.html

61. Schubert, C., 1999. Glaciers of South America - Glaciers of Venezuela. In: Satellite Image Atlas of Glaciers of The World, R.S. Williams, Jr., and J.G. Ferrigno, eds., U.S. Geological Survey Professional Paper 1386-I1, United States Government Printing Office, Washington, DC.

62. Serreze, M.C., J.E. Walsh, F.S. Chapin III, T. Osterkamp, M. Dyurgerov, V. Romanovsky, W.C. Oechel, J. Morison, T. Zhang and R.G. Barry, 2000. Observational evidence of recent change in the northern highlatitude environment. Climatic Change, 46: 159-207.

63. Shrestha, A.B., C.P. Wake, P.A. Mayewski, J.E. Dibb, 1999. Maximum temperature trends in the Himalaya and its vicinity: An analysis based on temperature records from Nepal for the period 1971-94. Journal of Climate, 12: 2775-2787.

64. Stirling, I. et al., 1999. Long term trends in the population ecology of polar bears in Western Hudson Bay in relation to climatic change, Arctic 53, 3: 292-306.

65. State of the Canadian Cryosphere, 2002. Past variability of Canadian glaciers. University of Waterloo. http://www.socc.uwaterloo.ca/glaciers/glaciers_hist_e.cfm.

66. Thompson, L.G., T. Yao, E. Mosley-Thompson, M.E. Davis, K. Henderson, K., and P.-N. Lin, 2000. A highresolution millennial record of the South Asian Monsoon from Himalayan Ice Cores. Science, 289: 19161919.

67. UN, 2000. Warning of famine in Tajikistan, UN appeals for some $\$ 77$ million for drought aid. September 19 , 2000. United Nations.

68. UN, 2001. Millions of people in East Asia hit by heavy monsoon rains as Central Asia is gripped by drought; Near East reels from three consecutive years of drought," FAO Press Release 01/63. 28 September 2001, Food and Agriculture Organization of the United Nations.

69. 2000. http://www.grida.no/aral/aralsea/english/climat/climats.htm

70. UNEP, 2002. Impact of global warming on mountain areas confirmed by UNEP-backed mountaineers. GRIDArendel News, United Nationas Environmental Program. June 5, 2002.

71. WMO, 2002b. The drought in central and southern Asia. World Climate News, No. 20, January 2002, World Meteorological Organization, Geneva, Switzerland.

72. http://www.wmo.ch/web/catalogue/New\%20HTML/frame/engfil/wcn/wcn20.pdf 